University of Zurich

Department of Economics

Working Paper Series

ISSN 1664-7041 (print)

ISSN 1664-705X (online)

Working Paper No. 360

\title{
Does Market Interaction Erode Moral Values?
}

Björn Bartling, Ernst Fehr and Yagiz Özdemir

Revised version, January 2021 


\title{
Does Market Interaction Erode Moral Values?*
}

\author{
Björn Bartling \\ Ernst Fehr \\ Yagiz Özdemir \\ University of Zurich \\ University of Zurich \\ University of Zurich
}

January 8, 2021

\section{Review of Economics and Statistics: Forthcoming}

The widespread use of markets leads to unprecedented material well-being in many societies. We study whether market interaction, as a side effect, erodes moral values. In an influential paper, Falk and Szech (2013) provide experimental data that seem to suggest that "market interaction erodes moral values." Although we replicate their main treatment effect, we show that additional treatments are necessary to corroborate their conclusion. These treatments reveal that playing repeatedly, and not market interaction, causes the erosion of moral values. Our paper thus shows that neither Falk and Szech's data nor our data support the claim that markets erode morals.

Keywords: Market interaction, moral values

JEL classification: C91, D02, D62, D91

\footnotetext{
* Department of Economics, Blümlisalpstrasse 10, 8006 Zurich, Switzerland. Bartling: bjoern.bartling@econ.uzh.ch. Fehr: ernst.fehr@econ.uzh.ch, Özdemir: yagiz.oezdemir@gmail.com. We thank the editor, four referees, and Friedrich Breyer, Armin Falk, Nora Szech, and Joachim Weimann for their comments on this paper.
} 


\section{Introduction}

Does market interaction erode moral values? Scholars have debated this question for centuries (e.g., Montesquieu 1748, Smith 1776, Marx 1859, Simmel 1900, Weber 1921, Schumpeter 1942, Polanyi 1944, Hirsch 1976, Shleifer 2004, Satz 2010, Frank 2011, Sandel 2012, Bruni and Sugden 2013, Bowles 2016, Storr and Choi 2019). Some scholars have argued that markets foster moral values, while others have blamed markets for undermining them. The widespread use of markets undoubtedly leads to unprecedented material well-being in many societies. Nonetheless, studying possible harmful "side effects" of market interaction is important. A broad understanding of market forces, including their possible impact on moral values, is necessary for policy makers and citizens to make informed decisions on the spheres in society where market should govern behavior and where other mechanisms might be preferable.

Studies seeking to identify the causal effect of markets on morals are scarce. ${ }^{1}$ A notable exception is Falk and Szech (2013), henceforth FS, who devised an intriguing experimental paradigm to study how markets affect morals: they measured subjects' willingness to pay for avoiding the death of a mouse. ${ }^{2}$ FS gave subjects in a one-period "non-market" treatment the choice between EUR 10 and the life of a mouse. In a 10-period bilateral "market" treatment with random re-matching, subjects in the role of "sellers" and "buyers" bargained about the split of EUR 20 in a double auction. If the bargaining partners agreed on a split, a mouse was killed. FS find that the fraction of subjects willing to accept EUR 10 in their one-period non-market treatment is significantly lower than the fraction of sellers willing to accept EUR 10 or less in their 10-period bilateral market treatment. FS conclude that "market interaction causally affects the willingness to accept severe, negative consequences for a third party" (p. 707) and that they "have shown that market interaction displays a tendency to lower moral values, relative to individually stated preferences” (p. 710). Given the fundamental importance of the question, here we examine whether these conclusions are justified. ${ }^{3}$

\footnotetext{
${ }^{1}$ A recent literature studies moral or socially responsible behavior in markets (e.g., Rode et al. 2008, Dufwenberg, et al. 2011, Bartling et al. 2015 and 2019, Hainmueller et al. 2015, Kirchler et al. 2015, Pigors and Rockenbach 2016, Irlenbusch and Saxler 2019, Danz et al. 2020, Ockenfels et al. 2020), but none of these papers focus on the causal effect of market interaction on moral values (an exception is a recent working paper by Ziegler et al., 2020). Correlational evidence based on cross-cultural studies shows that the level of market integration positively co-varies with prevailing fairness concerns in a society (Henrich et al. 2010).

${ }^{2}$ It was true that mice were kept alive or killed based on subjects' decisions. The mice were so-called "surplus mice" from animal experiments, and the default was for them to be killed. The experimenters purchased the mice that survived thanks to subjects' decisions and kept them in an appropriate environment.

${ }^{3}$ Earlier papers criticizing FS's interpretation of their data include Breyer and Weimann (2015) and Sutter et al. (2020).
} 
Our main point of concern is that FS compare behavior in a one-period non-market treatment to behavior in a 10-period market treatment. The treatment difference could thus be driven by the difference in the institutional context, which is what FS claim, but it might also be driven by the difference in the number of periods of play, or their interactions. In this paper, we therefore report the results of a $2 \times 2$ factorial design that varies both dimensions independently.

We organize the paper as follows. Section 2 describes our experimental design and its relation to FS's study. Section 3 presents the results, robustness checks, and a discussion of why playing repeatedly might undermine moral values. We conclude in Section 4.

\section{Experimental Design}

Subjects in our experiment must choose between either receiving additional money (up to CHF 20) or having the experimenter donate CHF 60 ( $\approx$ USD 65$)$ to a charity that uses this amount to fund the surgery for a leprosy patient in India. ${ }^{4}$ We test the hypothesis that subjects opt more frequently for receiving additional money - thereby accepting the consequence that a donation to charity will not be made-in our market treatments than in our non-market treatments.

\subsection{Market Treatments}

We randomly match subjects into pairs in our market treatments. Subjects in a pair bargain over the split of CHF 20 in a continuous double auction. The double auction lasts for three minutes. We informed the subjects that if they agree to a split, a donation of CHF 60 to fund a surgery of a leprosy patient in India will not be made. If a pair of subjects does not reach an agreement within three minutes, either because one of the two subjects refuses to agree to any split or because their claims are incompatible, neither subject receives an additional payment and the experimenter will donate CHF 60 to charity. If a pair of subjects reaches an agreement within three minutes, the subjects receive the respective monetary amounts, but the experimenter will not donate to the charity. Agreeing to a split thus imposes a negative externality on a leprosy patient in India.

Both subjects can continuously post binding offers by entering how much of the CHF 20 they demand for themselves (offer $=C H F 20$-demand). Offers can consist of any integer amount between 0 and 20. An improvement rule is in place, i.e., subjects must reduce their demands if they want to post a new offer. Only a subject's current offer can be accepted.

\footnotetext{
${ }^{4}$ Using donations to charity is a common tool to study moral behavior in the laboratory, see, e.g., Exley (2016) as an example. This has the advantage that studies are easy to replicate.
} 
We conducted a one-period treatment, labeled Market, and a treatment were the double auction was played repeatedly for 10 periods, with random re-matching of the subjects, labeled Market-10. We informed the subjects upfront that one of the 10 periods in Market-10 would be randomly drawn at the end of the session and that only the decisions made in this period would be implemented.

\subsection{Non-Market Treatments}

We also randomly matched subjects into pairs in our non-market treatments. One of the subjects is an active decision maker; the other subject is a passive recipient who cannot make any decision. Active subjects decide for all 21 possible integer splits of CHF 20 between themselves and the passive subject in a pair whether to accept the additional money. The active subject's share mirrors the "demand" in the market treatments and the passive subject's share mirrors the "offer" in the market treatments. We informed the subjects that one of the 21 decisions would be randomly drawn and implemented at the end of the session, and that the experimenter would only donate CHF 60 to fund a surgery of a leprosy patient in India if the active player rejected the randomly drawn split. As in the market treatments, agreeing to the receipt of additional money thus results in a negative externality on a leprosy patient in India.

We conducted a one-period treatment, labeled Non-Market, and a treatment were the active subjects repeatedly made their decisions for all the 21 possible integer splits for 10 periods, labeled Non-Market-10. Subjects remained in their roles as either active or passive players throughout the 10 periods of treatment Non-Market-10. We informed the subjects upfront that one of the 10 periods would be randomly selected to be relevant for payments. Table 1 provides an overview of our $2 \times 2$ factorial design.

Table 1. Treatments

One period 10 periods

\begin{tabular}{lcc}
\hline \hline Market treatments & Market & Market-10 \\
Non-market treatments & Non-Market & Non-Market-10 \\
\hline \hline
\end{tabular}

Notes: The table shows our $2 \times 2$ factorial design that varies the institutional context and the number of periods of play independently of each other. 


\subsection{Discussion of Design Features}

To compare our results to those by FS, we follow FS in interpreting the negotiation of a split of a fixed amount of money in a bilateral double auction as a "market interaction" and the individual choice whether or not to accept a given amount of money in a price list as a "non-market decision." 5 The details of our experimental design, however, differ in several ways from FS's design.

An evident difference is the nature of the externality. While accepting additional money causes the mouse's death in FS's study, the negative externality in our study is on a leprosy patient in India. We deliberately considered a different kind of externality in order to improve our understanding of the robustness and the contexts in which results related to the effect of markets on morals exist.

We implemented additional design changes to eliminate differences between the market and non-market treatments in FS's experiment that we considered to be unrelated to differences between market and non-market contexts.

Subjects in FS's non-market treatment Individual have the binary choice between EUR 10 and a mouse's life. In FS's treatment Bilateral Market, pairs of subjects negotiate about the split of EUR 20, with the consequence that a mouse would die in case of an agreement. Hence, FS's treatments Individual and Bilateral Market differ, inter alia, in the following three dimensions: (i) The total amount of money traded off against the mouse's life is EUR 10 in their non-market treatment but EUR 20 in their market treatment. (ii) A single subject is involved in their non-market treatment, while two subjects are involved in their market treatment. (iii) The action space is binary in their non-market treatment, but there are 21 possible integer splits of EUR 20 in their market treatment. In contrast, we hold these three dimensions constant in our treatments: a subject's choice is always whether to agree to an integer split of CHF 20 between oneself and another subject. ${ }^{6}$ While we hypothesized that the differences outlined in this paragraph are of minor importance, they should nevertheless be eliminated in a clean experimental design. ${ }^{7}$

\footnotetext{
${ }^{5}$ We return to the important issue of the definition of a market at the end of the conclusions.

${ }^{6}$ FS report two control treatments, Individual price-list and Two participants, each partly addressing that amount of money, number of subjects, and action space is not held constant between treatments Individual and Bilateral Market. However, none of the control treatments holds all three dimensions constant at the same time, as our design does.

${ }^{7}$ Further differences involve details of the experimental implementation, all of which we hypothesized to be of minor importance. First, FS exposed their subjects to a video showing how mice die from poisonous gas through slow suffocation. While subjects made their decisions directly after having seen the video in the individual choice treatment, they first played a trial period of the double auction before making their first decision in the market treatment. A time gap was thus present only in the market treatment, which might have attenuated a possible impact of the video on behavior. In our study, subjects first play a trial period of the double auction and are then informed about the externality,
} 
Finally, FS implement their non-market treatment Individual as a one-period game and compare it to behavior in their treatment Bilateral market, which is played repeatedly for 10 periods. We hypothesized that behavioral changes between FS's treatments Individual and Bilateral Market might be driven by two differences: market vs. non-market, and playing one period vs. 10 periods. For this reason, we added two experimental conditions to be able to keep the number of periods constant, at 1 and at 10 periods, when we compare market to non-market behavior. Our $2 \times 2$ factorial design, as summarized in Table 1, thus allows us to separate the impact of these two potentially important dimensions.

\subsection{Measurement of Moral Values}

We measure moral values by eliciting subjects' reservation prices for accepting the consequence that the experimenter will not donate CHF 60 for the surgery of a leprosy patient in India. The higher a subject's reservation price, the higher his or her moral values.

Consider treatments Non-Market and Non-Market-10 first. The reservation price of subject $i$ in period $t$, denoted by $R P_{i t}$, is the lowest monetary payment to the subject at which he or she prefers the money to the donation. If subject $i$ prefers the donation to all splits of CHF 20 in period $t$, even to the one that gives the subject CHF 20, then $R P_{i t}>20$.

Consider treatments Market and Market-10 next. If subject $i$ accepts an offer in period $t$, then let $a_{i t}$ denote the accepted amount. If subject $i$ does not accept any offer in period $t$, then $a_{i t}>20$. Let $d_{i t}$ denote the lowest amount that subject $i$ demands (and would thus be willing to accept) in period $t$. If subject $i$ does not post any demand in period $t$, then $d_{i t}>20$. If either $a_{i t} \leq$ 20 or $d_{i t} \leq 20$, then the reservation price of subject $i$ in period $t$ is measured as $R P_{i t}=$ $\min \left(a_{i t}, d_{i t}\right)$. If a subject neither posts a demand nor accepts an offer in period $t$, then $R P_{i t}>20$.

Note that neither we nor FS in their study can directly observe reservation prices in the market treatments. Suppose, for example, that subject $i$ does not post a demand and accepts the matched subject's offer to split the CHF 20 equally in period $t$. Subject $i$ 's reservation price would then be measured as $R P_{i t}=10$. However, we cannot observe the lowest monetary amount that

which aims to keep the time gap between being exposed to the externality and making a (first) decision constant in all treatments. Second, FS framed subjects' decisions as choices between two trivia quizzes (where correct answers lead to additional earnings) in treatment Individual but not in Bilateral Market. We frame subjects' decisions as choices between money and donation in all treatments. Third, FS label subjects in the double auction as buyers and sellers and consider only the sellers' choices. We treat our subjects in the double auction symmetrically and consider all subjects' choices. 
subject $i$ would have accepted. $R P_{i t}$ is thus an upper bound because the true reservation price might be lower.

For reasons of comparability with FS, we use the same aggregate measure of moral values that FS use, namely the fraction of subjects with a reservation value of 10 or less ( $R P \leq 10)$. As a robustness check, we will also consider an alternative aggregate measure of the subjects' moral values, namely the fraction of subjects willing to accept any feasible amount of money ( $R P \leq 20)$. This aggregate measure is unaffected (as we will explain in more detail below) by the possibility that a subject succeeds in getting a share of the CHF 20 that exceeds his or her reservation price.

Finally, since treatments Non-Market-10 and Market-10 generate a measure of a subject's reservation price in each of the 10 periods, the question of how to summarize the information for each subject arises. FS use each subject's lowest reservation price over the course of all 10 periods to calculate the fraction of subjects with $R P \leq 10$. For reasons of comparability, we will follow

this approach, that is, $R P_{i}=\min _{t} R P_{i t}$. However, as robustness checks, we will also base our two aggregate measures of moral values (the fractions of subjects with $R P \leq 10$ and the fraction with $R P \leq 20$ ), on subjects' median reservation prices, and we will compare the aggregate measures period by period between treatments Non-Market-10 and Market-10, i.e., we study whether markets erode moral values in any of the 10 periods.

\subsection{Measurement of Social Norms}

A necessary condition for being able to study moral values is a context that the experimental subjects perceive as being morally relevant. To test whether our design is suitable for addressing our research question, we measured the social norm regarding the choice to accept additional CHF 20 with the consequence that the experimenter does not donate CHF 60 for the surgery of a leprosy patient in India.

We elicited the social norm relating to the choice of taking CHF 20, i.e., the largest amount of money that a subject could get in our treatments, with the consequence that there would be no donation. Moreover, we measured the norm in a choice environment without a passive player, who would receive CHF 0 if the active player takes CHF 20. Moral excuses for taking the money should be largest when CHF 20 are at stake and no passive player without earnings is present, which stacks the deck against the finding that taking the money in our experimental paradigm is morally 
inappropriate. We use the coordination game approach developed by Krupka and Weber (2013) as our measurement tool for the social norm.

A separate sample of subjects who did not participate in any of our four treatments participated in the norm measurement task. ${ }^{8}$ We asked these participants whether most people would rate a subject's choice to take the CHF 20 as "socially acceptable and consistent with moral and appropriate behavior" or as "socially inacceptable and inconsistent with moral and appropriate behavior." Subjects could select either "very acceptable," "somewhat acceptable," "neutral,” “somewhat inacceptable," or "very inacceptable.” Importantly, we did not ask subjects to provide the rating that they believe to be right, but the rating that they believe the other subjects in a session would most frequently choose. We assume this social norm serves as the focal point in this coordination game. Subjects received CHF 10 if their answers matched the modal response.

\subsection{Procedural Details}

All sessions took place in the laboratory of the Department of Economics at the University of Zurich. Subjects were students from the University of Zurich and the Swiss Federal Institute of Technology in Zurich. ${ }^{9}$ We conducted the study with z-Tree (Fischbacher 2007) and h-Root (Bock et al. 2014). Before entering the lab, subjects drew random numbers that allocated them to computer terminals and, in treatments Non-Market and Non-Market-10, determined a subject's role as either active or passive player. Subjects received written instructions, including comprehension questions that they had to answer correctly before a session could begin. We provide the instructions in the online appendix. Sessions with one-period treatments lasted about 1 hour; sessions with 10-period treatments about 1.5 hours. In total, 604 subjects participated in the study. 102 active (and 102 passive) subjects participated in six sessions of treatment Non-Market, 98 active (and 98 passive) subjects participated in six sessions of treatment Non-Market-10, 98 subjects participated in three sessions of treatment Market, and 106 subjects participated in four sessions of treatment Market10. Each subject received a show-up fee of CHF 15 and an additional payment between CHF 0 and CHF 20 depending on the decisions made in the experiment. A donation of CHF 10'860 was made to the Swiss charity FAIRMED, which could finance 181 basic surgeries for leprosy patients in India costing CHF 60 on average.

\footnotetext{
${ }^{8}$ The data were collected in the context of the study by Bartling and Özdemir (2017).

${ }^{9}$ We thus study a different subject pool than FS, whose experiments were conducted in Bonn. Note also that the purchasing power of CHF 1 in Zurich is lower than the purchasing power of EUR 1 in Bonn.
} 


\section{Results}

We first note that the subjects perceive the trade-off in our experimental paradigm as morally relevant. The measurement of the social norm pertaining to taking CHF 20, instead of having the experimenter donate CHF 60 for a leprosy patient in India, provides a clear result. 98 percent of the subjects (61 out of 62) believe that most subjects rate the decision to take the money as either "very" or "somewhat socially inappropriate." The former is the modal choice (32 out of 62). Only one subject believed that "neutral" is the most frequent rating. No subject opted for "somewhat" or "very appropriate." We conclude from these data that our experimental paradigm is suited for studying moral conflict. ${ }^{10}$

\subsection{Replication of FS's Treatment Difference}

FS focus on the fraction of subjects with $R P \leq 10$ for accepting negative consequences for a third party, when they compare moral values in their one-period treatment Individual to behavior in their 10-period treatment Bilateral Market. In this section, we follow their approach of focusing on the fraction of subjects with $R P \leq 10$ to test whether we can replicate their main empirical result.

Panel (a) of Figure 1 shows the fraction of subjects with $R P \leq 10$ in our treatments NonMarket and Market-10. Panel (b) shows the fraction of subjects with $R P \leq 10$ in FS's corresponding treatments Individual and Bilateral Market.

Figure 1 reveals that we closely replicate FS's treatment difference. The fraction of subjects with $R P \leq 10$ increases from 41.2 percent (42 of 102) in treatment Non-Market to 74.5 percent (79 of 106) in treatment Market-10 (two-sided Fisher exact test, $p<0.001$ ). These fractions are very similar to the respective fractions of 46.0 percent (57 of 124) and 72.2 percent (26 of 36), reported by FS. ${ }^{11}$ We thus observe a lower moral standard in the 10-period market treatment than in the one-period non-market treatment in both FS's mouse paradigm as well as in our leprosy paradigm. ${ }^{12}$ We summarize this first result in the following.

\footnotetext{
${ }^{10}$ These data were first reported in Bartling and Özdemir (2017).

${ }^{11}$ Two-sided Fisher exact tests confirm that the fractions of subjects with $R P \leq 10$ do not differ significantly between our and FS's study, neither when comparing Non-Market and Individual $(p=0.502)$, nor when comparing Market10 and Bilateral Market $(p=0.827)$.

${ }^{12}$ Taken together, the differences in our and FS's experimental design, as outlined in Section 2.3, thus do not affect the results.
} 
Result 1: The main treatment difference reported by Falk and Szech (2013) is replicated in our study: Moral values are lower in our 10-period market treatment than in our one-period non-market treatment.

Figure 1. Replication of FS’s Treatment Difference
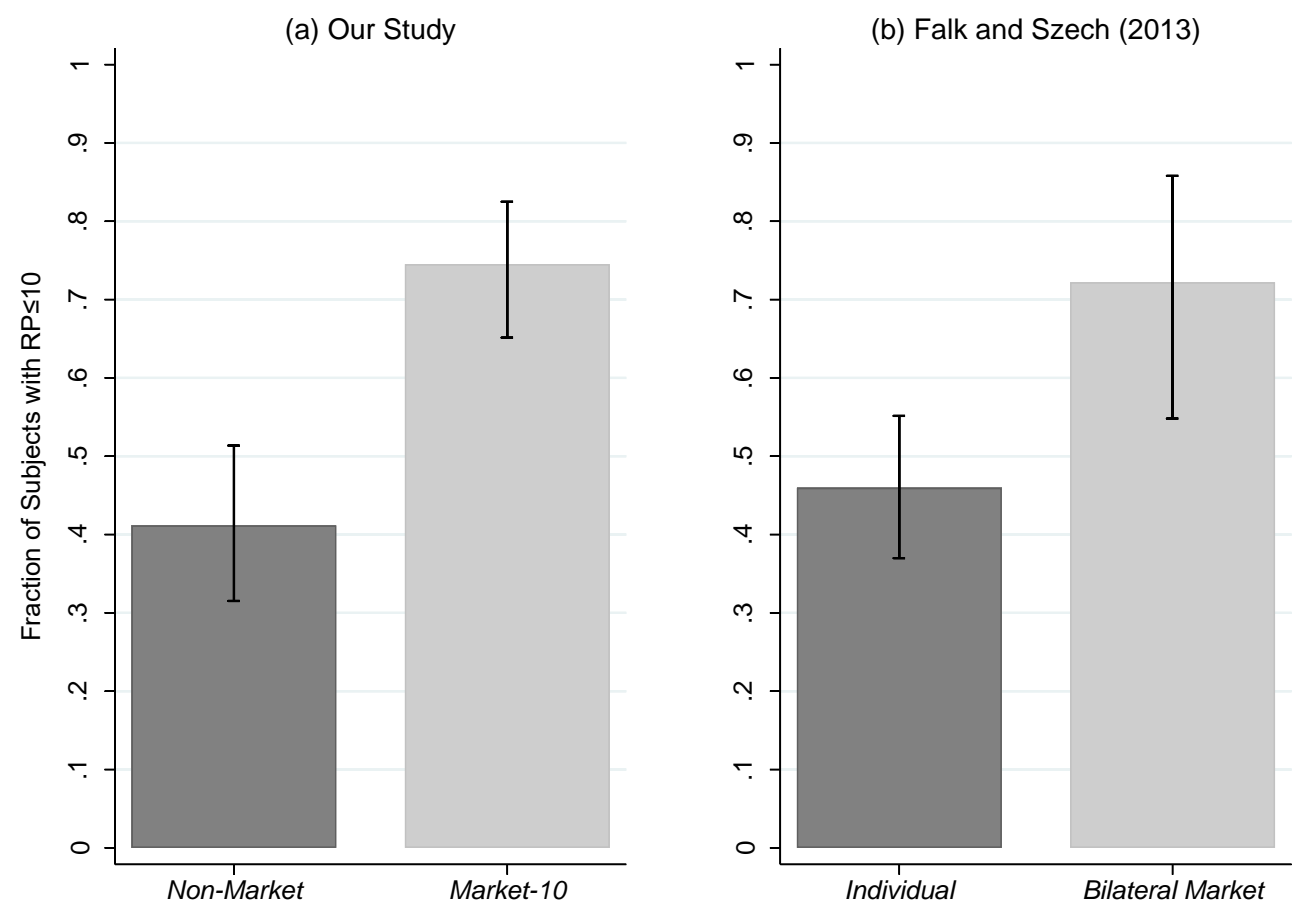

Notes: Panel (a) shows the fraction of subjects with a reservation price of CHF 10 or less for accepting negative consequences for a third party in our one-period treatment Non-Market and in our 10-period treatment Market-10. The higher the fraction of subjects with a reservation price of CHF 10 or less, the lower the moral values. Panel (b) shows the respective fractions in FS's one-period treatment Individual and in their 10-period treatment Bilateral Market. Error bars indicate exact binomial 95\% confidence intervals. The figure reveals that moral values are lower in our 10period market treatment than in our one-period non-market treatment, which closely replicates the treatment difference between Individual and Bilateral Market reported by FS.

\subsection{Moral Values when Controlling for Number of Periods}

FS claim that the market institution causes the lower moral values observed in treatment Bilateral Market than in Individual. However, since FS compare a one-period non-market treatment to a 10period market treatment, their main result could equally be driven by the difference in the number of periods played, or by the interaction of repetition and institutional context. Our fully factorial design allows us to disentangle the impact of market interaction on moral values from the impact of playing repeatedly. 
Panel (a) in Figure 2 illustrates the comparison of moral values in our market and nonmarket treatments when we hold the number of periods constant at 1 . We find that the fraction of subjects with $R P \leq 10$ is 41.8 percent (41 of 98) in treatment Market, which is virtually identical to treatment Non-Market (41.2 percent, 42 of 102; two-sided Fisher exact test, $p=1.000$ ).

The same finding prevails if we hold the number of periods constant at 10. Panel (b) of Figure 2 reveals that we do not find a significant difference between the fractions of subjects with $R P \leq 10$ in treatments Non-Market-10 and Market-10. The fraction of subjects with $R P \leq 10$ is 69.4 percent (68 of 98) in Non-Market-10 and 74.5 percent (79 of 106) in Market-10 if we classify subjects based on their minimum reservation prices (two-sided Fisher exact test, $p=0.438$ ). The respective fractions are 57.1 percent (56 of 98) and 56.6 percent (60 of 106) if we classify subjects based on their median reservation prices (two-sided Fisher exact test, $p=1.000$ ).

Figure 2. Moral Values when Controlling for Number of Periods
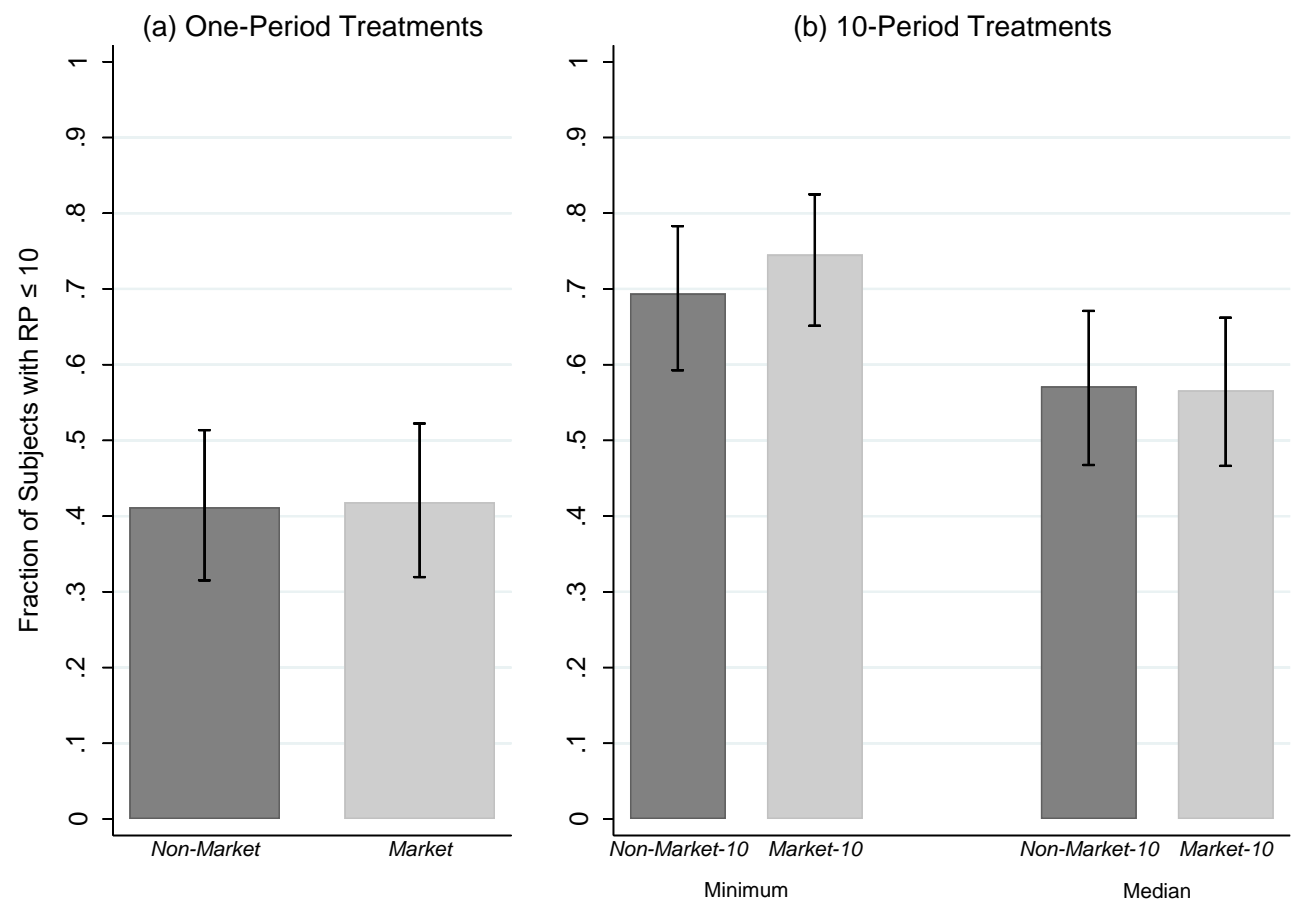

Notes: Panel (a) shows that the fractions of subjects with a reservation price of CHF 10 or less for accepting negative consequences for a third party are virtually identical in our one-period treatments Non-Market and Market. Panel (b) shows that the fractions of subjects with a reservation price of CHF 10 or less in our 10-period treatments Non-Market10 and Market-10 are not significantly different, irrespective of whether subjects are classified according to their minimum reservation price (left pair of bars) or according to their median reservation price (right pair of bars) over all 10 periods. Error bars indicate exact binomial 95\% confidence intervals. The figure reveals that moral values are not affected by the institutional context — market or non-market—if the number of periods of play is held constant. 
Our fully factorial design thus reveals that market interaction-as implemented by FS and in our experiment-does not affect the willingness to accept negative consequences for a third party. Our data thus do not support the claim that "market interaction erodes moral values."

Rather, we find that playing repeatedly causes the erosion of moral values both in our market and non-market treatments. The fraction of subjects with $R P \leq 10$ is significantly lower in the one-period than in the 10-period treatments, irrespective of whether we classify subjects according to their minimum reservation prices (one-sided Fisher exact test, $p<0.001$ both in the market and non-market treatments) or according to their median reservation price ( $p=0.024$ and $p=0.017$ in the market and non-market treatments, respectively). We summarize these findings next.

Result 2: (a) Moral values are not different in our market and non-market treatments if we control for the number of periods. (b) Moral values are lower in our 10-period than in our one-period treatments.

\subsection{Robustness Checks}

Figure 3 plots the cumulative distribution function of reservation prices. Panel (a) shows treatments Non-Market and Market; panel (b) shows treatments Non-Market-10 and Market-10. In the latter treatment pair, we show subjects’ minimum reservation prices.

Panel (a) reveals that there are far fewer observations for reservation prices below 10 in treatment Market than in treatment Non-Market. However, there is a relatively large number of reservation prices of exactly 10, about 25 percent, in treatment Market, such that the fraction of subjects with $R P \leq 10$ is almost identical in treatments Non-Market and Market. The vertical dashed line at a reservation price of 10 facilitates detecting this pattern in the figure. In contrast, the distributions of reservation prices above 10 is similar in treatments Non-Market and Market. Panel (b) shows that the exact same pattern prevails in treatments Non-Market-10 and Market-10. The distributions suggest that many of the subjects with a reservation price below 10 find a "trading partner” in the market treatments with whom they can split the CHF 20 equally.

Figure 3 illustrates the problem that the amount a subject receives in case of an agreement in the market treatments can be an overestimation of his or her reservation price. Focusing on the fraction of subjects with $R P \leq 10$ addresses the problem partially because this measure does not 
distinguish between reservation prices in the range of prices up to 10. However, mismeasurement of reservation prices in the market treatments can affect the classification of subjects into those with $R P \leq 10$ and those with $R P>10$. Suppose, for example, that subject $i$ has a reservation price of 8, does not post a demand, and accepts an offer from the matched subject that gives subject $i$ a monetary payoff of 12. Subject $i$ would then be classified as a subject with $R P>10$, even though subject $i$ is a subject with $R P \leq 10$. In the non-market treatments, in contrast, where a price list is used to measure reservation prices directly, subject $i$ would be classified correctly.

Figure 3. Cumulative Distribution of Reservation Prices
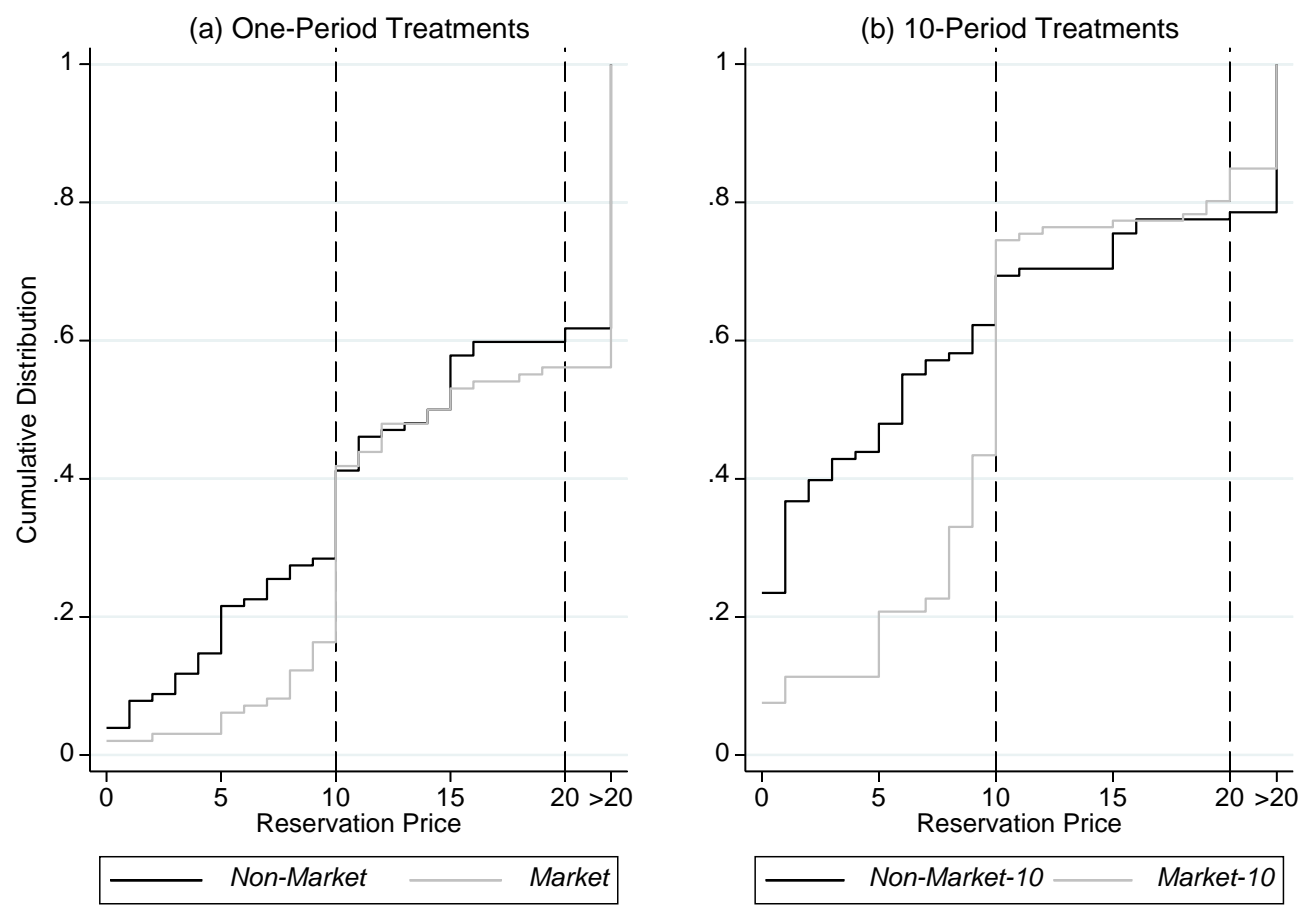

Notes: Panel (a) shows the cumulative density functions of the reservation prices in treatments Non-Market (black line) and Market (grey line). Panel (b) shows the cumulative density functions in treatments Non-Market-10 (black line) and Market-10 (grey line). Subjects in the 10-period treatments are classified according to their minimum reservation price over all 10 periods. Subjects with a reservation price larger than 20 are included as a separate category to the right of the vertical dashed line at 20. The vertical dashed line at 10 highlights the fact that the fractions of subjects with a reservation prices of 10 or less are very similar in the market and non-market treatments, both in panel (a) and panel (b). The figure reveals that reservation prices below 10 are less frequent but reservation prices of exactly 10 are more frequent in the market treatments than in the non-market treatments. The distribution of reservation values is relatively similar in the market and non-market treatments in the range of reservation prices above 10.

As an additional robustness check of the finding that moral values are not different in our market and non-market treatments, we distinguish in the following between subjects who indicate a willingness to accept any of the feasible amounts $(R P \leq 20)$ and subjects who refuse all feasible 
amounts $(R P>20)$. This approach applies the same yardstick to the non-market and market treatments because it is not possible for a subject with $R P \leq 20$ to reach an agreement in the market treatments that gives the subject more than CHF 20, and leads to being classified as a subject with $R P>20$. A subject might receive a share of the CHF 20 that exceeds his or her reservation price, but measurement error in the range of CHF 20 or less is irrelevant when we consider the fraction of subjects with $R P \leq 20$ as our aggregate measure of moral values. In our above example, subject $i$ with a reservation price of 8 would be correctly classified as a subject with $R P \leq 20$, both in the market and in the non-market treatments.

In the following, we thus study whether subjects in our market treatments are "lured" into accepting any amount of money up to CHF 20. We find that none of our results change. The fraction of subjects with $R P \leq 20$ is not different in the one-period treatments Non-Market and Market (61.8 percent (63 of 102) vs. 56.1 percent (55 of 98), two-sided Fisher exact test, $p=0.473$ ). The same holds for the comparisons between treatments Non-Market-10 and Market-10. The fraction of subjects with $R P \leq 20$ is not significantly different, irrespective of whether we base the classification on minimum reservation prices (78.6 percent (77 of 98) vs. 84.9 percent (90 of 106), two-sided Fisher exact test, $p=0.277$ ) or on median reservation prices (72.4 percent (71 of 98) vs. 74.5 percent (79 of 106), two-sided Fisher exact test, $p=0.753$ ).

Using the fraction of subjects with $R P \leq 20$ as our aggregate measure of moral values, we can also replicate that playing repeatedly causes an erosion of moral values. This holds irrespective of whether we classify subjects according to their minimum reservation prices (one-sided Fisher exact test, $p<0.001$ and $p=0.007$ in the market and non-market treatments, respectively) or according to their median reservation prices ( $p=0.004$ and $p=0.073$, respectively).

Figure 4 finally shows the fractions of subjects with $R P \leq 10$ and with $R P \leq 20$ over time. We classify the subjects in each period according to their reservation price in that period. The figure shows that moral values, measured by the fraction of subjects with either $R P \leq 10$ (back lines) or $R P \leq 20$ (grey lines) in a given period, are very similar in every single period of treatments NonMarket-10 (dashed lines) and Market-10 (solid lines). Irrespective of whether we consider the fraction of subjects with $R P \leq 10$ or the fraction of subjects with $R P \leq 20$, moral values are not significantly different between the market and non-market treatments in any period (two-sided Fisher exact tests, $p \in\{0.403 ; 1.000\}$ for $R P \leq 10$, and $p \in\{0.282 ; 1.000\}$ for $R P \leq 20)$. Figure 4 also shows that, on average, moral values are stable over time. 
Figure 4. Moral Values over Time

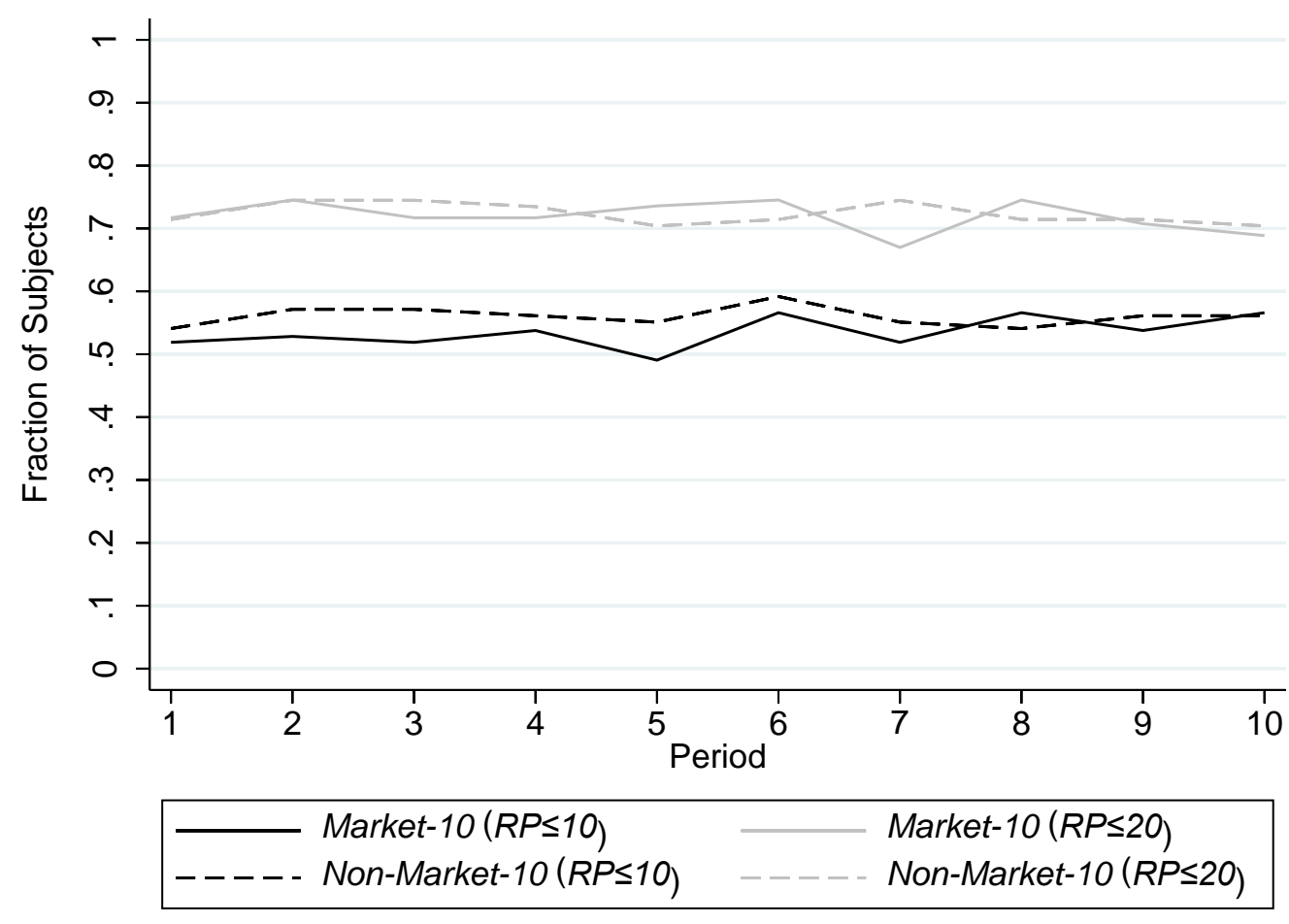

Notes: The black lines show the fractions of subjects with a reservation price of CHF 10 or less $(R P \leq 10)$ for accepting negative consequences for a third party in each period separately. The grey lines show the fractions of subjects with a reservation price of CHF 20 or less $(R P \leq 20)$. The solid lines show the fractions for treatment Market-10; the dashed lines show the fractions for treatment Non-Market-10. The figure reveals that moral values, as measured by subjects' reservation pieces, are very similar in treatments Non-Market-10 and Market-10. There is not a single period in which moral values are significantly different, irrespective of whether we consider the fraction of subjects with $R P \leq 10$ or the fraction of subjects with $R P \leq 20$.

\subsection{Playing Repeatedly and Moral Values}

We found that the difference in the number of repetitions, not the difference in the institutional context, underlies the finding that moral values are lower in our 10-period market than in our oneperiod non-market treatment. The question arises why playing repeatedly undermines moral values.

Here we provide a brief, exploratory analysis focussing on the fraction of subjects with $R P \leq 10$ in the non-market treatments, where we can measure reservation prices directly. The analysis reveals a pattern that could be interpreted as being consistent with theories of moral licensing and moral cleansing. Moral licensing occurs if moral behavior in one period serves as a license for immoral behavior in a later period. Moral cleansing occurs if immoral behavior in one period is followed by moral behavior in a later period to restore a moral (self) image. ${ }^{13}$

\footnotetext{
${ }^{13}$ See, e.g., Blanken et al. (2015) and Mullen and Monin (2016) for recent surveys of the literature.
} 
We find that about 40 percent of our subjects in treatment Non-Market-10 (41 of 98) display stable behavior; they indicate the same reservation price in each period. The remaining roughly 60 percent indicate different reservation prices at least once over the course of the 10 periods. The fraction of the stable subjects with $R P \leq 10$ in treatment Non-Market-10 is 41.5 percent (17 of 41), which is identical to the fraction of subjects with $R P \leq 10$ in the one-period treatment Non-Market (41.2 percent, 42 of 102; two-sided Fischer exact test, $p=1.000$ ). The larger overall fraction of subjects with $R P \leq 10$ in treatment Non-Market-10 than in Non-Market (Result 2b) is thus entirely driven by the unstable subjects. Interestingly, if we calculate the fraction of unstable subjects with $R P \leq 10$ based on these subjects' "most moral" choices (i.e., on their maximum reservation prices over time), then the fraction of unstable subjects with $R P \leq 10$ drops to 42.1 percent (24 of 57 ), which is again identical to the fraction of subjects with $R P \leq 10$ in treatment Non-Market (two-sided Fischer exact test, $p=1.000$ ). The lower moral values in treatment Non-Market-10 than in Non-Market (Result 2b) are thus driven by unstable subjects who have the same moral standards as the subjects in treatment Non-Market in at least one period (indicated by the unstable subjects' maximum reservation prices), but who deviate to a lower standard in at least one other period (indicated by their minimum reservation prices). Unstable subjects' moral choices in early periods might thus serve as a license to behave less morally in later periods. Likewise, the anticipation of the possibility to make more moral choices in later periods might allow subjects to behave less morally in earlier periods.

We would also like to point to the design feature that only one of the 10 periods is randomly selected to be relevant for payment in the games with repetition (both in FS and in our design), which might provide subjects with “moral wiggle room” (e.g., Dana et al. 2006, 2007). Since we designed our experiment to study the robustness of FS's main finding and not to study exhaustively how playing repeatedly might influence (moral) behavior, we cannot disentangle the impact of playing repeatedly from the impact of a random payment protocol.

Finally, on a methodological note, our data suggest that it is generally important to critically assess whether behavioral patterns observed in one-shot experimental settings extend to settings where subjects play repeatedly, and vice-versa. ${ }^{14}$

\footnotetext{
14 Imas et al. (2020) make the same point in the context of an experimental test of regret theory, demonstrating "potential pitfalls when extrapolating behavioral findings identified from one-shot choices to repeated settings” (p. 1).
} 


\section{Conclusions}

We study whether market interaction erodes moral values. Our experimental design follows FS, who provided data that seem to show that market interaction causes the erosion of moral values. Our novel experimental design eliminates several differences between FS's market and non-market treatments that appear unrelated to generic differences between the institutional contexts. Most notably, we control for the number of periods of play.

We closely replicate FS's main finding that moral values are lower in a 10-period market treatment than in a one-period non-market treatment. However, if we control for the number of repetitions, differences in moral values in our market and non-market treatments disappear. Our data clearly show that lower moral values in our 10-period market treatment than in our one-period non-market treatment are caused by playing repeatedly and not by the market institution. This finding suggests that the same holds for the difference between FS's one-period non-market treatment Individual and their 10-period treatment Bilateral Market. Thus, neither Falk and Szech’s data nor our data support the claim that market interaction erodes moral values.

Note that we do not show that market interaction generally does not erode moral values. The possibility that markets affect morals remains an interesting open research question, and FS's paper deserves credit for fueling this fundamentally important debate. It appears, however, that no widely shared view exists of what constitutes a market. In the words of Al-Ubaydli and List (2017): "Somewhat perversely for a concept so central to the discipline of economics, economists scarcely provide a definition of a market” (p. 274). To have a meaningful debate, it will be decisive to clarify the features that distinguish market and non-market environments. More specifically, it will be useful to clarify how to think about a market in an experimental study. For example, in which sense is a decision taken in a price list less of a market interaction than a decision taken in a double action ${ }^{15}$ Future research will then have to show, by providing clean causal evidence, whether markets make people selfish and corrupt, or whether markets might even encourage virtuous behavior.

${ }^{15}$ On this point, see also the discussion in Breyer and Weimann (2015). 


\section{References}

Al-Ubaydli, Omar and John List (2017). "Field Experiments in Markets.” Handbook of Economic Field Experiments. Vol. 1, 217-307. Eds.: Banerjee and Duflo. Amsterdam: North Holland.

Bartling, Björn and Yagiz Özdemir (2017). “The Limits to Moral Erosion in Markets: Social Norms and the Replacement Excuse." Working paper No. 262, Department of Economics, University of Zurich.

Bartling, Björn, Vanessa Valero, and Roberto Weber (2019). “On the Scope of Externalities in Experimental Markets.” Experimental Economics, 22(3), 610-24.

Bartling, Björn, Roberto Weber, and Lan Yao (2015). “Do Markets Erode Social Responsibility?” Quarterly Journal of Economics, 130(1), 219-66.

Blanken, Irene, Niels van de Ven, and Marcel Zeelenberg (2015). “A Meta-Analytic Review of Moral Licensing.” Personality and Social Psychology Bulletin, 41(4), 540-58.

Bock, Olaf, Andreas Nicklisch and Ingmar Baetge (2014). "hroot: Hamburg registration and organization online tool.” European Economic Review, 71, 117-20.

Bowles, Sam (2016). The Moral Economy: Why Good Incentives Are No Substitute for Good Citizens. New Haven: Yale University Press.

Breyer, Friedrich and Joachim Weimann (2015), “Of morals, markets and mice: Be careful drawing policy conclusions from experimental findings!” European Journal of Political Economy, 40, 387-90.

Bruni, Luigino, and Robert Sugden (2013). “Reclaiming Virtue Ethics for Economics” Journal of Economic Perspectives, 27(4), 141-64.

Dana, Jason, Daylian Cain, and Robyn Dawes (2006). “What you don’t know won’t hurt me: Costly (but quiet) exit in a dictator game.” Organizational Behavior and Human Decision Processes, 100(2), 193-201.

Dana, Jason, Roberto Weber, and Jason Kuang (2007). "Exploiting moral wiggle room: experiments demonstrating an illusory preference for fairness.” Economic Theory, 33, 67-80

Danz, David, Dirk Engelmann, and Dorothea Kübler (2020). “Do Legal Standards Affect Ethical Concerns of Consumers?” CRC TRR 190 Discussion Paper No. 234. 
Dufwenberg, Martin, Paul Heidhues, Georg Kirchsteiger, Frank Riedel, and Joel Sobel. (2011). “Other-regarding Preferences in General Equilibrium.” Review of Economic Studies, 78(2), 613-39.

Exley, Christine (2016). “Excusing Selfishness in Charitable Giving: The Role of Risk.” Review of Economic Studies, 83(2), 587-628.

Falk, Armin and Nora Szech (2013). “Morals and Markets.” Science, 340(6133), 707-11.

Fischbacher, Urs (2007). “z-Tree: Zurich toolbox for ready-made economic experiments.” Experimental Economics, 10(2), 171-78.

Frank, Robert (2011), The Darwin Economy: Liberty, Competition, and the Common Good. Princeton: Princeton University Press.

Hainmueller, Jens, Michael Hiscox, and Sandra Sequeira (2015). Consumer Demand for Fair Trade: Evidence from a Multistore Field Experiment. Review of Economics and Statistics, 97(2), 242-56.

Henrich, Joseph, Jean Ensminger, Richard McElreath, Abigail Barr, Clark Barrett, Alexander Bolyanatz, Juan Cardenas, Michael Gurven, Edwins Gwako, and Natalie Henrich (2010). "Markets, religion, community size, and the evolution of fairness and punishment." Science, 327(5972), 1480-84.

Hirsch, Fred (1976). Social Limits to Growth. Cambridge: Harvard University Press.

Imas, Alex, Diego Lamé, and Alistair Wilson (2020). “Reversals between one-shot and repeated decisions in incentive design: The case of regret.” Mimeo.

Irlenbusch, Bernd and David Saxler (2019). The role of social information, market framing, and diffusion of responsibility as determinants of socially responsible behavior. Journal of Behavioral and Experimental Economics, 80, 141-61.

Kirchler, Michael, Jürgen Huber, Matthias Stefan, and Matthias Sutter. 2016. “Market Design and Moral Behavior,” Management Science, 62(9), 2615-25.

Krupka, Erin and Roberto A. Weber (2013). "Identifying social norms using coordination games: Why does dictator game sharing vary?” Journal of the European Economic Association, 11(3), 495-524.

Marx, Karl (1867/1909-10). Capital: A Critique of Political Economy. Chicago: Kerr and Co. Montesquieu, Charles (1748/1989). The Spirit of the Laws. Cambridge: Cambridge UP. 
Mullen, Elizabeth and Benoit Monin (2016). “Consistency versus Licensing Effects of Past Moral Behavior.” Annual Review of Psychology, 67, 363-85.

Ockenfels, Axel, Peter Werner, and Ottmar Edenhofer (2020). “Pricing Externalities and Moral Behaviour.” Nature Sustainability, https://doi.org/10.1038/s41893-020-0554-1.

Pigors, Mark and Bettina Rockenbach. 2016. “Consumer Social Responsibility.” Management Science, 62(11), 3123-37.

Polanyi, Karl (1944/2001) The Great Transformation: The Political and Economic Origins of Our Time. Boston: Beacon Press.

Rode, Julian, Robin Hogarth, and Marc Le Menestrel (2008), Ethical Differentiation and Market Behavior: An experimental approach. Journal of Economic Behavior and Organization, 66, 265-80.

Sandel, Michael. 2012. What Money Can’t Buy. The Moral Limits of Markets. London: Alan Lane. Satz, Debra. 2010. Why Some Things Should Not Be for Sale: The Moral Limits of Markets. Oxford: Oxford University Press.

Schumpeter, Joseph (1942/1994). Capitalism, Socialism and Democracy. London: Routledge.

Shleifer, Andrei (2004). “Does competition destroy ethical behavior?” American Economic Review, 94(2), 414-18.

Simmel, Georg (1900/1990). The Philosophy of Money. London and New York: Routledge.

Smith, Adam (1776/1979). An Inquiry into the Nature and Causes of the Wealth of Nations. Oxford: Clarendon Press.

Storr, Virgil and Ginny Choi (2019). Do Markets Corrupt Our Morals? London: Palgrave Macmillan.

Sutter, Matthias, Jürgen Huber, Michael Kirchler, Matthias Stefan, and Markus Walzl (2020). Where to Look for the Morals in Markets? Experimental Economics, 23, 30-52.

Weber, Max (1921/1978). Economy and Society: An Outline of Interpretive Sociology. Berkeley: University of California Press.

Ziegler, Andreas, Giorgia Romagnoli, and Theo Offerman (2020). “Morals in Multi-Unit Markets.” Tinbergen Institute Discussion Papers 20-072/I, Tinbergen Institute. 


\title{
ONLINE APPENDIX
}

\section{Does Market Interaction Erode Moral Values?*}

\author{
Björn Bartling \\ Ernst Fehr \\ Yagiz Özdemir \\ University of Zurich \\ University of Zurich \\ University of Zurich
}

January 8, 2021

* Department of Economics, Blümlisalpstrasse 10, 8006 Zurich, Switzerland. Bartling: bjoern.bartling@econ.uzh.ch.
Fehr: ernst.fehr@econ.uzh.ch, Özdemir: yagiz.oezdemir@gmail.com. 
In this appendix, we present English translations of the written instructions used in this study (for active decision makers). Original instructions were in German. The original German instructions are part of the replication material in the Review of Economics and Statistics Dataverse: https://dataverse.harvard.edu/dataverse/restat

\section{1) Treatment Non-Market (instructions for active decision makers)}

\section{Welcome to the Econ-Lab!}

Please read the following instructions carefully. If you have questions, please raise your hand; an assistant will come immediately to you at your desk.

\section{General Information}

You are participating in a study at the Department of Economics at the University of Zurich. You will receive a fix payment of CHF 15 for your participation; you can earn additional monetary amounts depending on how the study runs. You will receive your payment at the end of the study in cash.

Please note that these instructions are only for your private information, and that communication is absolutely forbidden during the study. If you have questions, please address them to us. Violation of this rule leads to exclusion from the study and all payments.

The data collected in this study will never be associated with your name. Your name will only be used in signing the receipt for your payment, meaning that your anonymity is guaranteed at all times.

\section{What is this about?}

In this experiment, you will be assigned anonymously to another participant, participant 2. Participant 2 is in the role of a passive participant who can make no decisions and whose payment depends on your decisions. You will see a list of 21 scenarios on your monitor. You must decide for one of two alternatives in each scenario, alternative A or alternative B.

Alternative $A$ is the same in all 21 scenarios: If alternative $\mathbf{A}$ is realized, we will fund a necessary operation for a person suffering from leprosy in India, who otherwise would have no opportunity to have this operation. In this case, you and participant 2 will not receive any further monetary payment, meaning that you will receive your fixed payment of CHF 15 at the end of the study.

If, however, alternative B is realized, we will not fund the operation for the person suffering from leprosy. In this case, you and the passive participant will receive a combined additional monetary payment in the amount of CHF 20. The exact distribution of the CHF 20 varies between the individual scenarios.

At the end of the experiment, one scenario will be chosen randomly and your decision from the chosen round will be implemented. 
We will explain the consequences of the two alternatives in more detail below.

You have a total of three minutes of time to reach your decisions. After three minutes have expired, the study will continue with responses to a short questionnaire.

\section{The consequences of your actions}

Leprosy is a chronic infectious disease caused by the bacteria Mycobacterium Leprae; it is spread from person to person. The pathogen causes death of nerve cells and blockage of arteries and veins. As a result, there is a long-term danger of bodily disfigurement, blindness, or other permanent disabilities.
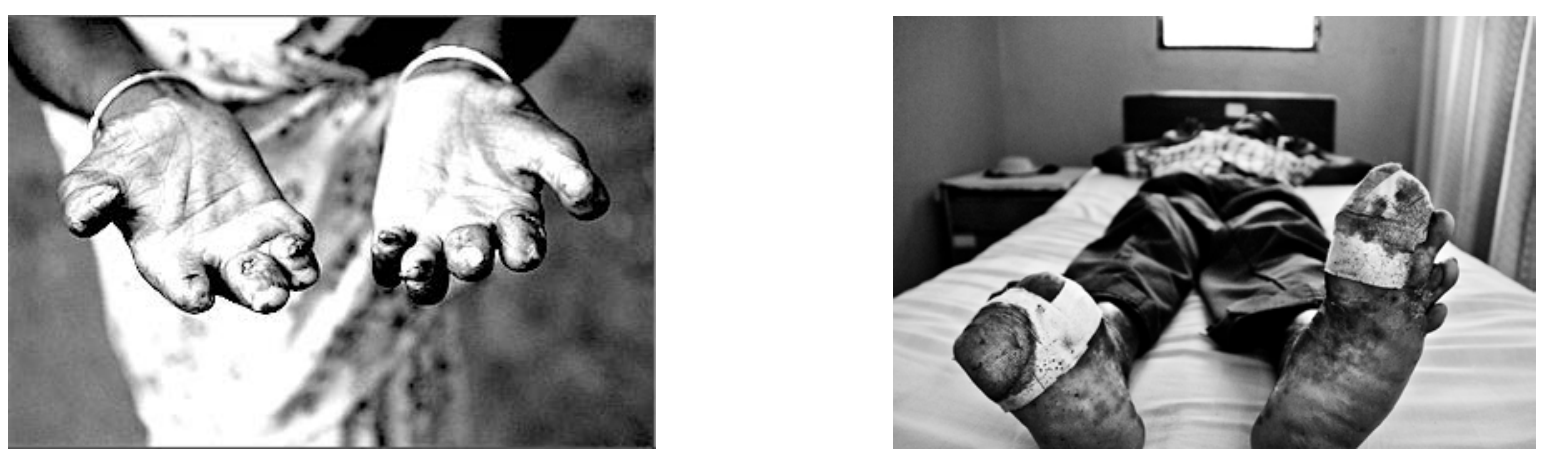

Although the disease can be cured with medical treatment, many leprosy victims suffer from the consequences of disfigurement from the sickness even after the pathogen has been eradicated. Disfigurement from leprosy leads to a very high degree of ostracism and stigmatization, a situation that victims suffer from for their entire lives. However, even small surgical interventions can significantly reduce the scope of disfigurement.

Almost $60 \%$ of the world's new leprosy cases occur in India. Due to the prevalence of poverty, funding an operation - which would allow for a life in dignity - is not possible for most of the victims with disfigurement.

If you select alternative $\mathbf{A}$ in the chosen scenario, we (the Department of Economics of the University of Zurich in cooperation with the Swiss relief organization FAIRMED) will fund the operation for a victim of leprosy in India. The cost of the operation depends on the extent of disfigurement. A simple procedure in India costs approximately CHF 60; the Department of Economics will cover this amount in full.

If you select alternative B in the chosen scenario, we will not provide the funding. This means that if an agreement is reached, the leprosy patient will not receive the operation. 


\section{Summary of possible results}

\begin{tabular}{|c|c|c|c|}
\hline Result & $\begin{array}{c}\text { Your additional } \\
\text { payment }\end{array}$ & $\begin{array}{c}\text { Participant 2's } \\
\text { additional } \\
\text { payment }\end{array}$ & $\begin{array}{c}\text { Consequence } \\
\text { for the person } \\
\text { suffering from } \\
\text { leprosy }\end{array}$ \\
\hline Alternative A & CHF 0 & CHF 0 & $\begin{array}{c}\text { Operation will } \\
\text { be done }\end{array}$ \\
\hline Alternative B & CHF X & $20-$ CHF X & $\begin{array}{c}\text { Operation will } \\
\text { not be done }\end{array}$ \\
\hline
\end{tabular}

Each of the 21 scenarios only varies with the value of $\mathrm{X}$ that applies in Alternative $\mathrm{B}$. X varies between CHF 0 and CHF 20. If, for example, $\mathrm{X}$ has the value of CHF 10, you and participant 2 will both earn an additional CHF 10, and an operation for a person suffering from leprosy will not be done if you select alternative B (= no operation) in the chosen round. In the same way, if X has the value of CHF 15 , then you will earn an additional CHF 15 and participant 2 will earn CHF 5 if you selected alternative $\mathrm{B}(=$ no operation $)$ in the chosen scenario.

If you select alternative $A$ in the chosen scenario, you and participant 2 will each receive the fix payment of CHF 15, will not earn any additional payment, and the value $\mathrm{X}$ plays no role in your payment.

\section{How you make your decision}

You must decide in each of the 21 scenarios, i.e. for each value of $\mathrm{X}$, whether you select alternative $\mathrm{A}$ (= operation for patient suffering from leprosy) or alternative B (= no operation for the patient suffering from leprosy). You will first be asked on the decision monitor how you decide for $\mathrm{X}=0$. After you have made your decision for $\mathrm{X}=0$, please make a decision for $\mathrm{X}=1$, then for $\mathrm{X}=2$, etc.

- If you always select alternative A (i.e. for all values of $\mathrm{X}$ beginning with $\mathrm{X}=0$ ), then you must always click on alternative $\mathrm{A}$ on the decision monitor.

- If you wish to choose alternative $A$ for smaller values of $X$ and want to change to $B$ for higher values of $\mathrm{X}$, then always click on alternative $\mathrm{B}$ beginning at that value of $\mathrm{X}$ where you wish to change. Please note in this case that you cannot switch back from $\mathbf{B}$ to $\mathbf{A}$. This means that if you change from $\mathrm{A}$ to $\mathrm{B}$ for a certain value of $\mathrm{X}$, then all higher values of $\mathrm{X}$ must also remain with alternative $B$.

- If you always select alternative $B$ (i.e. for all values of $X$ beginning with $X=0$ ), then you must always click on alternative $\mathrm{B}$ on the decision monitor. 


\section{Control questions}

Please answer the questions below to examine your understanding of the experiment. If you have any questions, please raise your hand.

1) Assume that $X=8$ in the scenario chosen at the end. What happens if you selected alternative $B$ in this scenario? Please mark the correct answer.

- You and participant 2 each earn a total of CHF 15 (fixed payment) and an operation will be performed on a patient suffering from leprosy.

- You earn a total of CHF 23 (fixed payment of CHF 15 plus CHF 8), participant 2 earns a total of CHF 27 (fixed payment of CHF 15 plus CHF 12), and an operation will not be performed on a patient suffering from leprosy.

2) Assume that $X=17$ in the scenario chosen at the end. What happens if you selected alternative $A$ in this scenario? Please mark the correct answer.

- You and participant 2 each earn a total of CHF 15 (fixed payment) and an operation will be performed on a patient suffering from leprosy.

- You earn a total of CHF 32 (fixed payment of CHF 15 plus CHF 17), participant 2 earns a total of CHF 18 (fixed payment of CHF 15 plus CHF 3), and an operation will not be performed on a patient suffering from leprosy.

3) Assume that $X=0$ in the scenario chosen at the end.

- How much do you and participant 2 earn in addition to the fixed payment of CHF 15 if you select alternative $\mathrm{A}$ (= Operation)?

Participant 2's additional income: Your additional income:

- How much do you and participant 2 earn in addition to the fixed payment of CHF 15 if you select alternative $B$ (= No operation)?

Participant 2's additional income: Your additional income:

4) The operation on a leprosy patient has the objective of

- Destroying the pathogen that causes leprosy.

- Strongly relieving the consequences of disfigurement due to leprosy. 


\section{2) Treatment Non-Market-10 (instructions for active decision makers)}

\section{Welcome to the Econ-Lab!}

Please read the following instructions carefully. If you have questions, please raise your hand; an assistant will come immediately to you at your desk.

\section{General Information}

You are participating in a study at the Department of Economics at the University of Zurich. You will receive a fix payment of CHF 15 for your participation; you can earn additional monetary amounts depending on how the study runs. You will receive your payment at the end of the study in cash.

Please note that these instructions are only for your private information, and that communication is absolutely forbidden during the study. If you have questions, please address them to us. Violation of this rule leads to exclusion from the study and all payments.

The data collected in this study will never be associated with your name. Your name will only be used in signing the receipt for your payment, meaning that your anonymity is guaranteed at all times.

\section{What is this about?}

In this experiment, you will be assigned anonymously to another participant, participant 2 , in each of ten rounds. After each round, you will be randomly assigned to a new participant 2, and you will never be assigned to the same person twice. Participant 2 is in the role of a passive participant who can make no decisions and whose payment depends on your decisions. In each round, you will see a list of 21 scenarios on your monitor; the list is the same in all ten rounds. In each round, you must decide for one of two alternatives in each scenario, alternative A or alternative B.

Alternative $A$ is the same in all 21 scenarios: If alternative $\mathbf{A}$ is realized, we will fund a necessary operation for a person suffering from leprosy in India, who otherwise would have no opportunity to have this operation. In this case, you and participant 2 will not receive any further monetary payment, meaning that you will receive your fixed payment of CHF 15 at the end of the study.

If, however, alternative B is realized, we will not fund the operation for the person suffering from leprosy. In this case, you and the passive participant will receive a combined additional monetary payment in the amount of CHF 20. The exact distribution of the CHF 20 varies between the individual scenarios.

After each round, one scenario will be chosen randomly and your decision will be the result of that round. At the end of the experiment, one of the ten rounds will be chosen randomly and the result of the chosen round will be implemented.

We will explain the consequences of the two alternatives in more detail below. 
You have a total of three minutes of time in each round to make your decisions. The next round begins after three minutes have expired. The study will continue with responses to a short questionnaire after the tenth round.

\section{The consequences of your actions}

Leprosy is a chronic infectious disease caused by the bacteria Mycobacterium Leprae; it is spread from person to person. The pathogen causes death of nerve cells and blockage of arteries and veins. As a result, there is a long-term danger of bodily disfigurement, blindness, or other permanent disabilities.
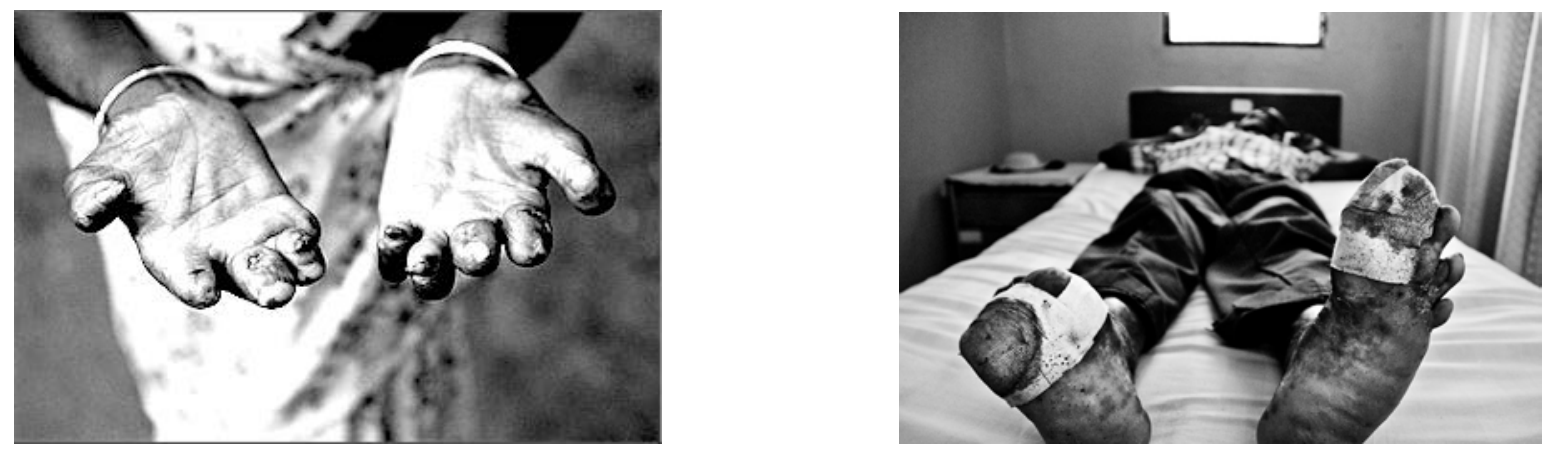

Although the disease can be cured with medical treatment, many leprosy victims suffer from the consequences of disfigurement from the sickness even after the pathogen has been eradicated. Disfigurement from leprosy leads to a very high degree of ostracism and stigmatization, a situation that victims suffer from for their entire lives. However, even small surgical interventions can significantly reduce the scope of disfigurement.

Almost $60 \%$ of the world's new leprosy cases occur in India. Due to the prevalence of poverty, funding an operation - which would allow for a life in dignity - is not possible for most of the victims with disfigurement.

If you select alternative $A$ in the chosen scenario of the round chosen at the end, we (the Department of Economics of the University of Zurich in cooperation with the Swiss relief organization FAIRMED) will fund the operation for a victim of leprosy in India. The cost of the operation depends on the extent of disfigurement. A simple procedure in India costs approximately CHF 60; the Department of Economics will cover this amount in full.

If you select alternative $B$ in the chosen scenario of the round chosen at the end, we will not provide the funding. This means that if an agreement is reached, the leprosy patient will not receive the operation. 


\section{Summary of possible results}

\begin{tabular}{|c|c|c|c|}
\hline Result & $\begin{array}{c}\text { Your additional } \\
\text { payment }\end{array}$ & $\begin{array}{c}\text { Participant 2's } \\
\text { additional } \\
\text { payment }\end{array}$ & $\begin{array}{c}\text { Consequence } \\
\text { for the person } \\
\text { suffering from } \\
\text { leprosy }\end{array}$ \\
\hline Alternative A & CHF 0 & CHF 0 & $\begin{array}{c}\text { Operation will } \\
\text { be done }\end{array}$ \\
\hline Alternative B & CHF X & $20-$ CHF X & $\begin{array}{c}\text { Operation will } \\
\text { not be done }\end{array}$ \\
\hline
\end{tabular}

Each of the 21 scenarios only varies with the value of $\mathrm{X}$ that applies in Alternative $\mathrm{B}$. $\mathrm{X}$ varies between CHF 0 and CHF 20. If, for example, $\mathrm{X}$ has the value of CHF 10, you and participant 2 will both earn an additional CHF 10, and an operation for a person suffering from leprosy will not be done if you select alternative $\mathrm{B}$ (= no operation) in the chosen scenario of the round chosen at the end. In the same way, if $\mathrm{X}$ has the value of CHF 15, then you will earn an additional CHF 15 and participant 2 will earn CHF 5 if you selected alternative B (= no operation) in the chosen scenario of the round chosen at the end.

If you select alternative $A$ in the chosen scenario of the round chosen at the end, you and participant 2 will each receive the fix payment of $\mathrm{CHF} 15$, will not earn any additional payment, and the value $\mathrm{X}$ plays no role in your payment.

\section{How you make your decision}

You must decide in each of the 21 scenarios, i.e. for each value of $\mathrm{X}$, whether you select alternative $\mathrm{A}$ (= operation for patient suffering from leprosy) or alternative B (= no operation for the patient suffering from leprosy). You will first be asked on the decision monitor how you decide for $\mathrm{X}=0$. After you have made your decision for $\mathrm{X}=0$, please make a decision for $\mathrm{X}=1$, then for $\mathrm{X}=2$, etc.

- If you always select alternative $A$ (i.e. for all values of $X$ beginning with $X=0$ ), then you must always click on alternative $\mathrm{A}$ on the decision monitor.

- If you wish to choose alternative $A$ for smaller values of $X$ and want to change to $B$ for higher values of $\mathrm{X}$, then always click on alternative $\mathrm{B}$ beginning at that value of $\mathrm{X}$ where you wish to change. Please note in this case that you cannot switch back from $\mathbf{B}$ to $\mathbf{A}$. This means that if you change from $\mathrm{A}$ to $\mathrm{B}$ for a certain value of $\mathrm{X}$, then all higher values of $\mathrm{X}$ must also remain with alternative $\mathrm{B}$.

- If you always select alternative $B$ (i.e. for all values of $X$ beginning with $X=0$ ), then you must always click on alternative $\mathrm{B}$ on the decision monitor. 


\section{Control questions}

Please answer the questions below to examine your understanding of the experiment. If you have any questions, please raise your hand.

1) Assume that $X=8$ in the chosen scenario of the round chosen at the end. What happens if you selected alternative $\mathrm{B}$ in this scenario? Please mark the correct answer.

- You and participant 2 each earn a total of CHF 15 (fixed payment) and an operation will be performed on a patient suffering from leprosy.

- You earn a total of CHF 23 (fixed payment of CHF 15 plus CHF 8), participant 2 earns a total of CHF 27 (fixed payment of CHF 15 plus CHF 12), and an operation will not be performed on a patient suffering from leprosy.

2) Assume that $X=17$ in the chosen scenario of the round chosen at the end. What happens if you selected alternative $\mathrm{A}$ in this scenario? Please mark the correct answer.

- You and participant 2 each earn a total of CHF 15 (fixed payment) and an operation will be performed on a patient suffering from leprosy.

- You earn a total of CHF 32 (fixed payment of CHF 15 plus CHF 17), participant 2 earns a total of CHF 18 (fixed payment of CHF 15 plus CHF 3), and an operation will not be performed on a patient suffering from leprosy.

3) Assume that $X=0$ in the chosen scenario of the round chosen at the end.

- How much do you and participant 2 earn in addition to the fixed payment of CHF 15 if you select alternative $\mathrm{A}$ (= Operation)?

Participant 2's additional income: ___ Your additional income:

- How much do you and participant 2 earn in addition to the fixed payment of CHF 15 if you select alternative $\mathrm{B}$ (= No operation)?

Participant 2's additional income: Your additional income:

4) The operation on a leprosy patient has the objective of

- Destroying the pathogen that causes leprosy.

- Strongly relieving the consequences of disfigurement due to leprosy. 


\section{3) Treatment Market}

\section{Part 1}

\section{Welcome to the Econ-Lab!}

Please read the following instructions carefully. If you have questions, please raise your hand; an assistant will come immediately to you at your desk.

\section{General Information}

You are participating in a study at the Department of Economics at the University of Zurich. You will receive a fix payment of CHF 15 for your participation; you can earn additional monetary amounts depending on how the study runs. You will receive your payment at the end of the study in cash.

Please note that these instructions are only for your private information, and that communication is absolutely forbidden during the study. If you have questions, please address them to us. Violation of this rule leads to exclusion from the study and all payments.

The data collected in this study will never be associated with your name. Your name will only be used in signing the receipt for your payment, meaning that your anonymity is guaranteed at all times.

\section{What is this about?}

In this experiment, you will be assigned anonymously to another of this study, participant 2 . In a virtual marketplace, you can negotiate with participant 2 about the final distribution of a monetary amount of CHF 20. The negotiations with participant 2 can lead either to an agreement or to no agreement. If you reach an agreement, each of you will receive the amount that you agreed on. If you do not reach an agreement with one of the participants, neither participant receives anything.

\section{How the market functions}

You can negotiate with participant 2 for the period of three minutes about the distribution of CHF 20. This means that you can place demands of how much of the CHF 20 you should receive; participant 2 can also make suggestions about how much of the CHF 20 he or she offers to you. You can accept the offer from participant 2 , and he or she can accept your demands.

Once demands and offers have been placed, they can no longer be withdrawn. When you enter a new demand, this must represent an improvement for participant 2, i.e. you must reduce your demand. The same applies for participant 2; if he or she suggests a new offer, this must be an improvement for you; i.e. participant 2 must increase his or her offer.

As soon as you enter a new - reduced - demand, your previous demands can no longer be accepted. The same applies for offers. As soon as you receive a new offer, you can no longer accept the previous offer. Only the current offers and demands can be accepted. 
You make a demand by entering the amount on your monitor that you would like to keep for yourself. If you enter a demand for CHF X, this means that you would like to retain CHF X for yourself and that participant 2 will thus receive the amount of CHF $20-\mathrm{X}$. This demand will then be notified to participant 2. The same applies for offers. If participant 2 offers you CHF Y, he or she will enter it on the monitor. An offer of Y means that you will receive the amount of CHF Y in case of an agreement, while participant 2 receives CHF $20-$ Y.

Demands must be integers between CHF 0 and 20.

The market will be closed when

a) an agreement is made (i.e. you accept an offer from participant 2, or when participant 2 accepts your demand)

or

b) the three minutes have expired.

\section{Summary of the market}

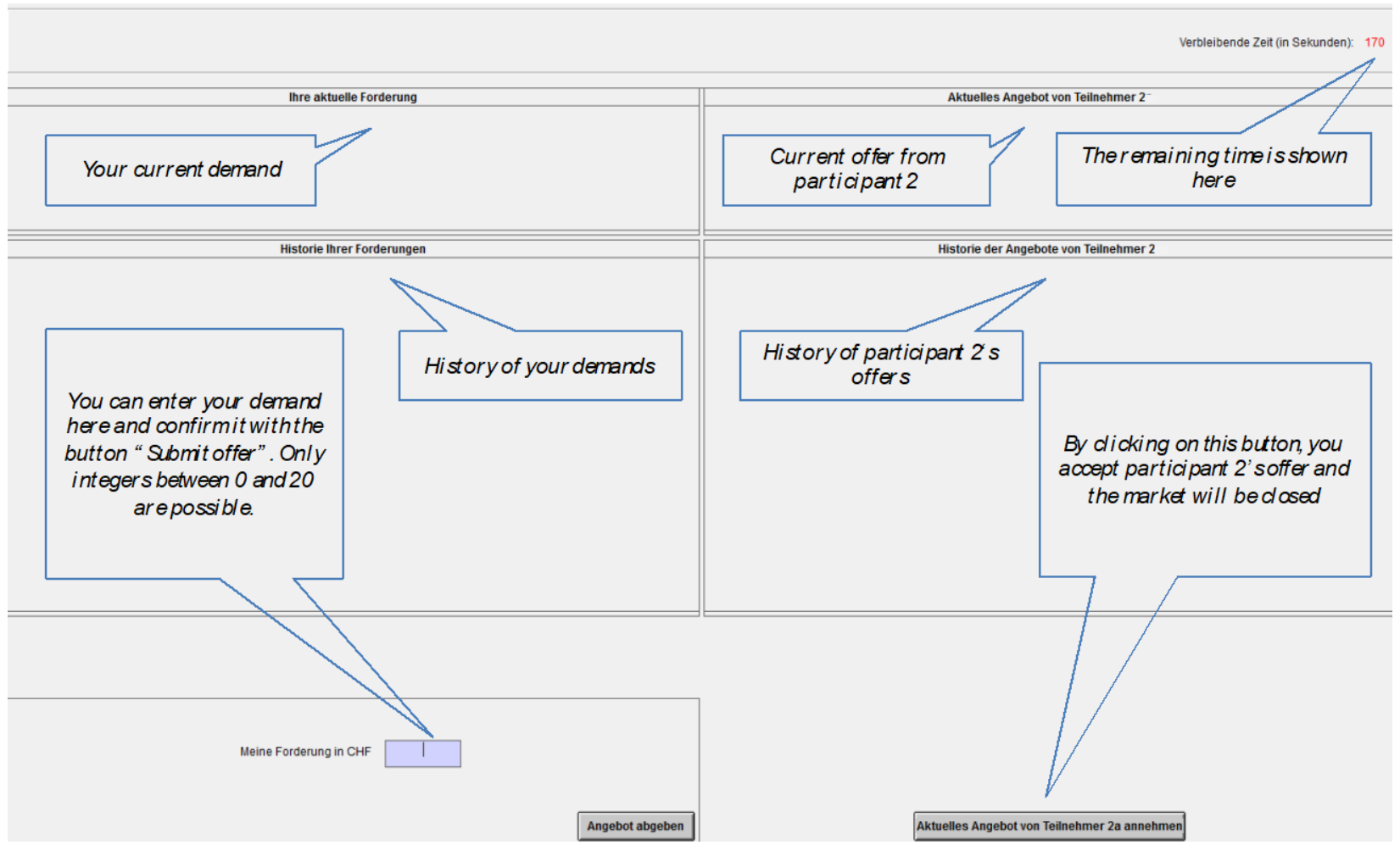

You now have the opportunity to become familiar with the operation of the virtual market for three minutes in a test run. You will be randomly grouped with another participant in the experiment. The test run has no consequences and only has the objective of helping you understand how the virtual market functions.

Please answer the control questions below and raise your hand as soon as you are done. 


\section{Control questions}

Question 1

Assume that you see the amount of CHF 5 in the window "Current offer from participant 2". If you click on "Accept current offer from participant 2", this means that you

- Accept the distribution "CHF 5 for me and CHF 15 for participant 2".

- Accept the distribution "CHF 15 for me and CHF 5 for participant 2"

\section{Question 2}

After you or participant 2 has accepted an offer,

- More demands and offers can be made until the three minutes have expired.

- No further demands and offers can be made because the market is closed.

\section{Part 2 (distributed only after the control questions for Part 1 were answered)}

After you were anonymously assigned to participant 2, the market will be open to you once for three minutes. The interaction with participant 2 can either lead to an agreement or not lead to an agreement. However, agreement or non-agreement also has consequences for a third party - a patient suffering from leprosy in India.

If no agreement is reached, then we will fund a necessary operation for a person suffering from leprosy in India, who otherwise would have no opportunity to have this operation. In this case, you and participant 2 will not receive any further monetary payment, meaning that you will receive your fixed payment of CHF 15 at the end of the study.

If, however, an agreement is reached, we will not fund the operation for the person suffering from leprosy. In this case, you and participant 2 will receive an additional monetary payment in the amount of the agreed sum.

We will explain the consequences of the two alternatives in more detail below.

If you do not reach an agreement with participant 2 within the three minute time period, the market will be closed with the result "no agreement". We will then fund the operation for a leprosy patient. After expiration of the 3 minutes, the experiment will be continued with a small questionnaire. 


\section{The consequences of your actions}

Leprosy is a chronic infectious disease caused by the bacteria Mycobacterium Leprae; it is spread from person to person. The pathogen causes death of nerve cells and blockage of arteries and veins. As a result, there is a long-term danger of bodily disfigurement, blindness, or other permanent disabilities.
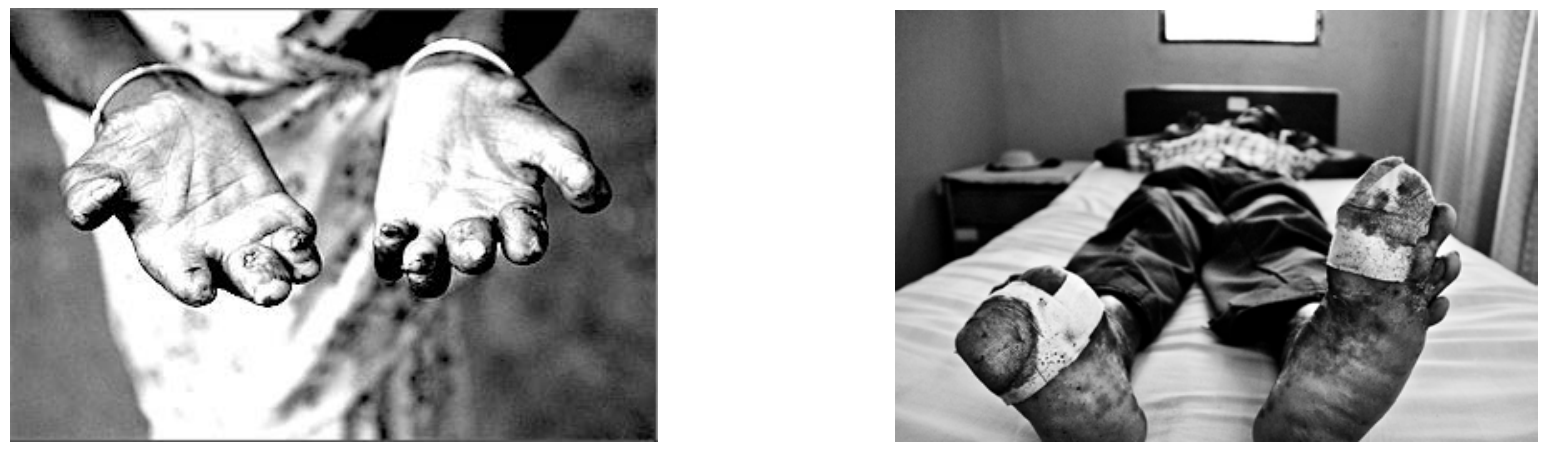

Although the disease can be cured with medical treatment, many leprosy victims suffer from the consequences of disfigurement from the sickness even after the pathogen has been eradicated. Disfigurement from leprosy leads to a very high degree of ostracism and stigmatization, a situation that victims suffer from for their entire lives. However, even small surgical interventions can significantly reduce the scope of disfigurement.

Almost 60\% of the world's new leprosy cases occur in India. Due to the prevalence of poverty, funding an operation - which would allow for a life in dignity - is not possible for most of the victims with disfigurement.

If you do not reach an agreement with participant 2 about the division of the additional monetary payment, we (the Department of Economics of the University of Zurich in cooperation with the Swiss relief organization FAIRMED) will fund the operation for a victim of leprosy in India. The cost of the operation depends on the extent of disfigurement. A simple procedure in India costs approximately CHF 60; the Department of Economics will cover this amount in full.

If you reach an agreement with participant 2 about the division of the additional monetary payment, we will not provide the funding. This means that if an agreement is reached, the leprosy patient will not receive the operation. 


\section{Summary of possible results}

\begin{tabular}{|c|c|c|c|c|}
\hline Result & $\begin{array}{c}\text { How is the } \\
\text { result reached? }\end{array}$ & $\begin{array}{c}\text { Your additional } \\
\text { payment }\end{array}$ & $\begin{array}{c}\text { Additional } \\
\text { payment for } \\
\text { participant 2 }\end{array}$ & $\begin{array}{c}\text { Consequence } \\
\text { for the person } \\
\text { suffering from } \\
\text { leprosy }\end{array}$ \\
\hline No agreement & $\begin{array}{c}\text { Three minutes } \\
\text { elapse without } \\
\text { you or } \\
\text { participant 2 } \\
\text { making or } \\
\text { accepting an } \\
\text { offer }\end{array}$ \\
Agreement - & $\begin{array}{c}\text { You or } \\
\text { participant 2 } \\
\text { accepts the } \\
\text { corresponding } \\
\text { offer within the } \\
\text { three minutes }\end{array}$ & CHF 0 & CHF 0 & $\begin{array}{c}\text { Operation will } \\
\text { be done }\end{array}$ \\
\hline
\end{tabular}

If, for example, you accept an offer from participant 2 for CHF 10, you and participant 2 will both earn an additional CHF 10, and an operation for a person suffering from leprosy will not be done. In the same way, if participant 2 accepts a demand from you for CHF 15, then you will earn an additional CHF 15 and participant 2 will earn CHF 5; again, an operation for a person suffering from leprosy will not be done.

If both you and participant 2 do not agree to anything, you both will each receive the fix payment of CHF 15, will not earn any additional payment, and the operation will be done for a person suffering from leprosy. 


\section{Control questions}

Please answer the questions below to examine your understanding of the experiment. If you have any questions, please raise your hand. An assistant will come to you at your desk and answer your question. Please mark the correct answer below.

\section{Question 1}

If you allow the three minutes on the screen to lapse without making a demand or accepting an offer,

- A person suffering from leprosy in India will receive an operation, and you and participant 2 will receive no further monetary payments.

- A person suffering from leprosy in India will not receive an operation, and you and participant 2 will receive no further monetary payments.

\section{Question 2}

If you click on "Accept the current offer from participant 2",

- A person suffering from leprosy in India will receive an operation, and you and participant 2 each receive the agreed upon amount as an additional monetary payment.

- A person suffering from leprosy in India will not receive an operation, and you and participant 2 each receive the agreed upon amount as an additional monetary payment.

- A person suffering from leprosy in India will not receive an operation, and you and participant 2 will receive no further monetary payments.

\section{Question 3}

The operation on a leprosy patient has the objective of

- Destroying the pathogen that causes leprosy.

- Strongly relieving the consequences of disfigurement due to leprosy. 


\section{5) Treatment Market-10}

\section{Part 2 (Part 1 is identical for treatments Market and Market-10)}

The market will be open to you for ten rounds lasting three minutes each. After three minutes have elapsed, you will be randomly assigned to a new participant 2, and you will never be assigned to the same person twice. At the end of the last round, one of the ten rounds will be chosen randomly and the result of the chosen round will be implemented. The interaction with participant 2 can either lead to an agreement or not lead to an agreement. However, agreement or non-agreement also has consequences for a third party - a patient suffering from leprosy in India.

If no agreement is reached in the chosen round, then we will fund a necessary operation for a person suffering from leprosy in India, who otherwise would have no opportunity to have this operation. In this case, you and participant 2 will not receive any further monetary payment, meaning that you will receive your fixed payment of CHF 15 at the end of the study.

If, however, an agreement is reached in the chosen round, we will not fund the operation for the person suffering from leprosy. In this case, you and participant 2 will receive an additional monetary payment in the amount of the agreed sum.

We will explain the consequences of the two alternatives in more detail below.

If you take no action or do not reach an agreement with participant 2 within the three minute time period, the market will be closed with the result "no agreement". If this round is chosen, we will then fund the operation for a leprosy patient. After expiration of the ten rounds, the experiment will be continued with a small questionnaire.

\section{The consequences of your actions}

Leprosy is a chronic infectious disease caused by the bacteria Mycobacterium Leprae; it is spread from person to person. The pathogen causes death of nerve cells and blockage of arteries and veins. As a result, there is a long-term danger of bodily disfigurement, blindness, or other permanent disabilities.
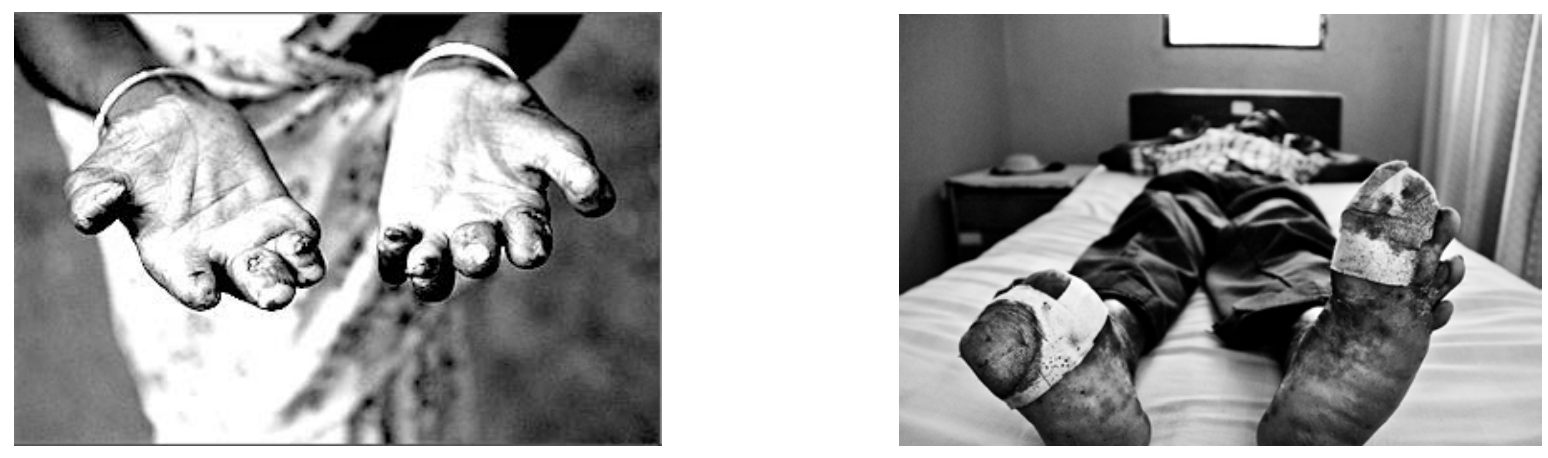

Although the disease can be cured with medical treatment, many leprosy victims suffer from the consequences of disfigurement from the sickness even after the pathogen has been eradicated. Disfigurement from leprosy leads to a very high degree of ostracism and stigmatization, a situation that victims suffer from for their entire lives. However, even small surgical interventions can significantly reduce the scope of disfigurement. 
Almost 60\% of the world's new leprosy cases occur in India. Due to the prevalence of poverty, funding an operation - which would allow for a life in dignity - is not possible for most of the victims with disfigurement.

If you do not reach an agreement with participant 2 about the division of the additional monetary payment, we (the Department of Economics of the University of Zurich in cooperation with the Swiss relief organization FAIRMED) will fund the operation for a victim of leprosy in India. The cost of the operation depends on the extent of disfigurement. A simple procedure in India costs approximately CHF 60; the Department of Economics will cover this amount in full.

If you reach an agreement with participant 2 about the division of the additional monetary payment, we will not provide the funding. This means that if an agreement is reached, the leprosy patient will not receive the operation.

\section{Summary of possible results}

\begin{tabular}{|c|c|c|c|c|}
\hline Result & $\begin{array}{c}\text { How is the } \\
\text { result reached? }\end{array}$ & $\begin{array}{c}\text { Your additional } \\
\text { payment }\end{array}$ & $\begin{array}{c}\text { Additional } \\
\text { payment for } \\
\text { participant 2 }\end{array}$ & $\begin{array}{c}\text { Consequence } \\
\text { for the person } \\
\text { suffering from } \\
\text { leprosy }\end{array}$ \\
\hline No agreement & $\begin{array}{c}\text { Three minutes } \\
\text { elapse without } \\
\text { you or } \\
\text { participant 2 } \\
\text { making or } \\
\text { accepting an } \\
\text { offer }\end{array}$ \\
Agreement - & $\begin{array}{c}\text { You or } \\
\text { participant 2 } \\
\text { accepts the } \\
\text { corresponding } \\
\text { offer within the } \\
\text { three minutes }\end{array}$
\end{tabular}

If, for example, you accept an offer from participant 2 for CHF 10, you and participant 2 will both earn an additional CHF 10, and an operation for a person suffering from leprosy will not be done. In the same way, if participant 2 accepts a demand from you for CHF 15, then you will earn an additional CHF 15 and participant 2 will earn CHF 5; again, an operation for a person suffering from leprosy will not be done.

If both you and participant 2 do not agree to anything, you both will each receive the fix payment of CHF 15, will not earn any additional payment, and the operation will be done for a person suffering from leprosy. 


\section{Control questions}

Please answer the questions below to examine your understanding of the experiment. If you have any questions, please raise your hand. An assistant will come to you at your desk and answer your question. Please mark the correct answer below.

\section{Question 1}

If you allow the three minutes on the screen to lapse in the round chosen at the end without making a demand or accepting an offer,

- A person suffering from leprosy in India will receive an operation, and you and participant 2 will receive no further monetary payments.

- A person suffering from leprosy in India will not receive an operation, and you and participant 2 will receive no further monetary payments.

\section{Question 2}

If you click on "Accept the current offer from participant 2" in the round chosen at the end,

- A person suffering from leprosy in India will receive an operation, and you and participant 2 each receive the agreed upon amount as an additional monetary payment.

- A person suffering from leprosy in India will not receive an operation, and you and participant 2 each receive the agreed upon amount as an additional monetary payment.

- A person suffering from leprosy in India will not receive an operation, and you and participant 2 will receive no further monetary payments.

\section{Question 3}

The operation on a leprosy patient has the objective of

- Destroying the pathogen that causes leprosy.

- Strongly relieving the consequences of disfigurement due to leprosy. 